\title{
International Normalizing Ratio (INR) pada pasien multitrauma di RSUP Prof. Dr. R. D. Kandou Manado
}

\author{
Verro Ratuwalangon \\ Laurens T. B. Kalesaran \\ Jimmy Panelewen \\ Heber B. Sapan
}

\author{
Bagian Ilmu Bedah Fakultas Kedokteran Universitas Sam Ratulangi Manado \\ RSUP Prof. Dr. R. D. Kandou Manado \\ Email: verrobedahmdo@yahoo.com
}

\begin{abstract}
Trauma is the leading cause of deaths in patients aged less than 45 years. Lifethreatening bleeding which usually occurs in multitraumatic patients is caused by vascular injury along with coagulopathy. Several studies on multitraumatic patients showed that the risk of coagulopathy occurred along with increasing Injury Severity Score (ISS) which is directly proportional to the increase of International Normalizing Ratio (INR) with an impact of increase of mortality rate. Although INR as an indicator of coagulopathy in multitraumatic patients is still unclear, early monitoring of coagulation is important to detect coagulopathy due to trauma. This study aimed to obtain the relationship of INR and multi-traumatic patients. This was an analytical study with a cross sectional design conducted in Energency Room Prof. Dr. R. D. Kandou Hospital Manado from December 2015 to March 2016. ISS for multi trauma was $>16$, meanwhile INR for coagulopathy risk was $>1.5$ and without that risk was $\leq 1.5$. There were 30 patients in this study aged 13-80 years old. Of 26 patients with ISS 17-25, one had INR $>1.5$. Moreover, ISS 26-59 was found in 4 patients; all had INR $>1.5$. All patients with INR $>1.5$ died. Conclusion: Increase of ISS was proportionally to increase of INR which was further proportionally to the increase of mortality rate in multiraumatic patients.
\end{abstract}

Keywords: coagulopathy, INR, ISS

\begin{abstract}
Abstrak: Trauma merupakan penyebab kematian utama pada pasein berusia kurang dari 45 tahun. Perdarahan yang mengancam nyawa pada pasien multitrauma biasanya disebabkan oleh cedera vaskular disertai koagulopati. Studi mengenai pasien multitrauma memperlihatkan adanya risiko koagulopati pada peningkatan nilai Injury Severity Score (ISS), yang secara proporsional sejalan dengan peningkatan nilai INR dengan akibat peningkatan angka kematian. Monitoring dini dari koagulasi sangat penting untuk mendeteksi terjadinya koagulopati akibat trauma. Walaupun demikian INR sebagai indikator koagulopati belum jelas. Penelitian ini bertujuan untuk menentukan hubungan INR dan pasien multitrauma agar dapat mengenali terjadinya koagulopati. Jenis penelitian ini analitik dengan desain potong lintang, dilaksanakan di Ruang Emergensi Bedah BLU RSUP Prof. R. D. Kandou Manado sejak Desember 2015 sampai dengan Maret 2016. Batasan multi trauma untuk ISS ialah skor $>16$, sedangkan batasan untuk INR dengan risiko koagulopati $>1,5$ dan yang tanpa risiko koagulopati $\leq 1,5$. Hasil penelitian mendapatkan 30 pasien multi trauma berusia 13-80 tahun. Pada kelompok ISS 17-25 terdapat 26 pasien; satu diantaranya dengan INR $>1,5$. Pada kelompok ISS 26-59 terdapat 4 pasien; semuanya mempunyai INR $>1,5$. Semua pasien dengan INR $>1,5$ meniggal. Simpulan: Peningkatan ISS proporsional dengan peningkatan INR yang selanjutnya proporsional terhadap peningkatan angka kematian pasien multitrauma. Keywords: koagulopati, INR, ISS
\end{abstract}


Hampir 25\% dari kasus trauma yang masuk di unit gawat darurat, didapati adanya koagulopati dengan berbagai tingkatan. Studi di Amerika Serikat, sekitar 40\% trauma fatal berhubungan dengan hemoragik dan syok hipovolemik, dan hampir semua pasien yang masuk rumah sakit dalam keadaan hidup pada akhirnya mengalami koagulopati saat kematian. ${ }^{1}$ Perdarahan yang mengancam jiwa pada pasien trauma biasanya disebabkan oleh kombinasi antara cidera vaskular dan koagulopati. Trauma mayor tidak hanya berakibat perdarahan karena kerusakan anatomi, tetapi lebih sering mengakibatkan koagulopati yang meningkatkan resiko kematian. $^{2}$

Berkontribusi untuk kehilangan darah adalah disregulasi intrinsik dari sistem pembekuan darah, yang saat ini sering disebut koagulopati yang disebabkan oleh trauma (Trauma Induced Coagulopathy/ TIC). TIC muncul pada keadaan hipoperfusi jaringan dari kehilangan darah dan cidera jaringan anatomi parah dan, tentu saja, sangat dikaitkan dengan meningkatnya angka kematian., 3 TIC awalnya digambarkan sebagai peningkatan dari International Normalizing Ratio (INR) oleh Brohi et al. pada pasien cidera parah yang diperiksa pada awal kedatangan di unit gawat darurat. ${ }^{5}$

Penelitian ini bertujuan mengetahui adanya hubungan sekaligus untuk mendapatkan gambaran distribusi nilai INR dengan pasien multi trauma, sehingga pada akhirnya bisa mengenali adanya risiko koagulopati pada pasien multitrauma.

\section{METODE PENELITIAN}

Penelitian ini merupakan desain prospektif dengan pendekatan cross sectional yang bersifat korelatif dengan menggunakan analisis korelasi Pearson untuk melihat hubungan INR dengan trauma serta gambaran distribusinya di BLU. Prof. Dr. R. D.Kandou Manado. Penelitian dilakukan di Instalasi Gawat Darurat Bedah BLU RSU Prof. R. D. Kandou, Manado, dan dilaksanakan mulai bulan Desember 2015 sampai Maret 2016.
Subjek penelitian ialah pasien multitrauma yang memenuhi kriteria inklusi yaitu: usia $>13$ tahun, jenis kelamin laki-laki dan perempuan, bersedia mengikuti penelitian dan mengisi formulir persetujuan. Multitrauma adalah cidera pada minimal 2 regio tubuh (AIS $\geq 3$ pada minimal 2 regio) atau dengan nilai ISS minimal 16, tanpa SIRS (Systemic Inflammatory Respon Syndrome). INR adalah rasio perbandingan antara nilai PT pasien dengan nilai PT standar, dengan nilai rata-rata normal $\leq 1,2$. Untuk batasan risiko koagulopati yaitu nilai INR $>1,5$ dan tanpa risiko koagulopati $\leq 1,5$. Hasil keluaran utama berupa pengelompokan skoring Injury Severity Score (ISS), kemudian dihubungkan antara skoring ISS dengan peningkatan nilai INR, dan selanjutnya dilihat angka mortalitas pada nilai INR yang didapat.

\section{HASIL PENELITIAN}

\section{Distribusi subyek penelitian menurut jenis kelamin, usia dan penyebab trauma}

Tabel 1 memperlihatkan 30 subjek penelitian yang terdiri dari 20 pasien lakilaki dan 10 pasien perempuan.

Tabel 1. Data subjek penelitian menurut jenis kelamin

\begin{tabular}{lcc}
\hline Jenis kelamin & Frekuensi & Persentase \\
\hline Laki-laki & 20 & 66,7 \\
Perempuan & 10 & 33,3 \\
Total & 30 & 100,0 \\
\hline
\end{tabular}

Tabel 2. Data subjek penelitian menurut usia

\begin{tabular}{ccc}
\hline Usia (tahun) & Frekuensi & Persentase \\
\hline $10-19$ & 9 & 30,0 \\
$20-29$ & 8 & 26,7 \\
$30-39$ & 5 & 16,7 \\
$40-49$ & 4 & 13,3 \\
$50-59$ & 2 & 6,7 \\
$60-69$ & 1 & 3,3 \\
$80-89$ & 1 & 3,3 \\
Total & 30 & 100,0 \\
\hline
\end{tabular}


Frekuensi tertinggi subyek penelitian ditemukan pada usia 10-19 tahun (Tabel 2) dengan penyebab trauma tersering ialah KLL (Tabel 3).

Tabel 3. Data subjek penelitian menurut penyebab trauma

\begin{tabular}{ccc}
\hline $\begin{array}{c}\text { Penyebab } \\
\text { trauma }\end{array}$ & Frekuensi & Persentase \\
\hline Dipukul & 3 & 10,0 \\
Ditikam & 5 & 16,7 \\
Jatuh & 6 & 20,0 \\
KLL & 16 & 53,3 \\
Total & 30 & 100,0 \\
\hline
\end{tabular}

\section{Data penelitian menurut ISS}

Semua pasien dibagi dalam 3 kelompok untuk nilai ISS, yaitu dengan nilai ISS $17-25$ berjumlah 26 pasien, nilai ISS 26-59 berjumlah 4 pasien. Dimana ada 3 pasien yang meninggal pada kelompok nilai ISS 17-25 dan pada kelompok nilai ISS 26-35 semua pasien meninggal.

Tabel 2. Data ISS subjek penelitian

\begin{tabular}{ccc}
\hline ISS & Frekuensi & Persentase \\
\hline $17-25$ & 26 & 86,6 \\
$26-35$ & 4 & 13,4 \\
$\geq 36$ & 0 & 0 \\
Total & 30 & 100 \\
\hline
\end{tabular}

\section{Data penelitian hubungan ISS dengan INR}

Dari pengelompokkan data nilai ISS dan data nilai INR didapati pasien dengan nilai ISS $17-25$ yang nilai INR-nya $\leq 1,5$ berjumlah 25 pasien, dan nilai INR-nya $>1,5$ pada 1 pasien, dan pasien dengan nilai ISS 26-35 yang nilai INR-nya $>1,5$ berjumlah 4 pasien.

Hubungan antara INR (numerik) dan ISS (numerik) dianalisis dengan analisis koefisien korelasi Pearson. Hasil analisis ini diperoleh $\mathrm{r}=0,834$ dengan $P<0,001$. Hasil ini menyatakan ada hubungan yang sangat bermakna dan kuat antara INR dan ISS $(P<0,001)$ yang berarti makin meningkat INR makin meningkat pula ISS.

Tabel 3. Data hubungan INR dengan ISS

\begin{tabular}{ccc}
\hline \multicolumn{2}{c}{ INR } \\
\hline ISS & $\leq 1,5$ & $>1,5$ \\
$17-25$ & $1,03-1,50$ & 1,52 \\
& $(25$ pasien $)$ & $(1$ pasien $)$ \\
$26-35$ & 0 & $1,54-2,14$ \\
& & $(4$ pasien $)$ \\
$\geq 36$ & 0 & 0 \\
\hline
\end{tabular}

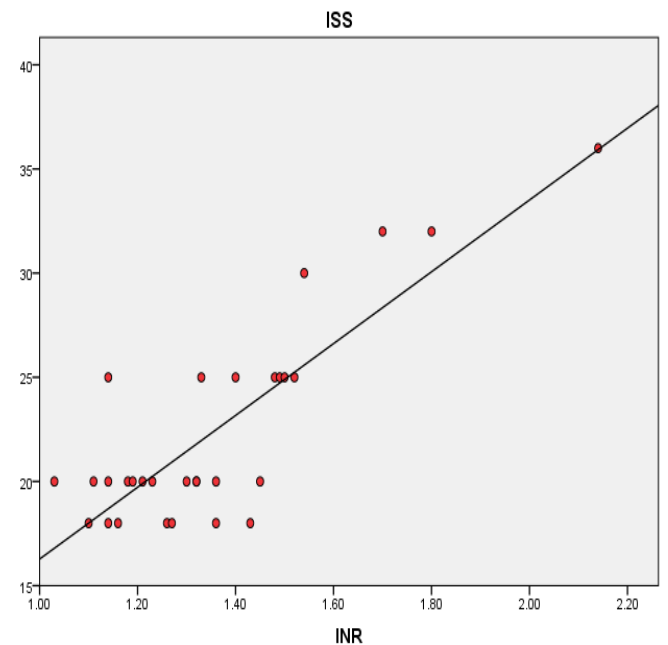

Gambar 1. Scatterplot hubungan INR dengan ISS

\section{Data penelitian menurut INR}

Dari data pemeriksaan INR, dikelompokkan menjadi nilai INR $\leq 1,5$ dan nilai INR $>1,5$. Pasien dengan nilai INR $\leq 1,5$ berjumlah 25 orang dan dengan nilai INR $>1,5$ berjumlah 5 orang.

Tabel 4. Data INR dalam subjek Penelitian

\begin{tabular}{cccc}
\hline & & Frekuensi & Persentase \\
\hline Valid & $\leq 1,5$ & 25 & 83,3 \\
& $>1,5$ & 5 & 16,7 \\
& Total & 30 & 100,0 \\
\hline
\end{tabular}


Hubungan antara INR (kategorik) dan kesembuhan (kategorik) dianalisis dengan analisis dengan uji $\chi^{2}$. Hasil analisis ini diperoleh $\chi^{2}=19,714$ dengan $P<0,001$. Hasil ini menyatakan ada hubungan yang sangat bermakna antara INR dan mortalitas yang berarti pasien yang memiliki INR tinggi cenderung meninggal.
Tabel 5. Pengujian hubungan INR dan mortalitas

\begin{tabular}{llccc}
\hline & \multicolumn{3}{c}{ Mortalitas } \\
& & Meninggal & Hidup & Total \\
\hline INR & $\leq 1,5$ & 2 & 23 & 25 \\
& $>1,5$ & 5 & 0 & 5 \\
Total & & 7 & 23 & 30 \\
\hline
\end{tabular}

Tabel 6. Chi-Square test

\begin{tabular}{lcccc}
\hline & Value & Df & $\begin{array}{c}\text { Asymp. Sig. } \\
(\text { 2-sided })\end{array}$ & $\begin{array}{c}\text { Exact Sig. } \\
\text { (1-sided) }\end{array}$ \\
\hline $\begin{array}{l}\text { Pearson Chi-Square } \\
\text { Fisher's Exact Test }\end{array}$ & $19.714^{\mathrm{a}}$ & 1 & .000 & .000 \\
$\mathrm{~N}$ of Valid Cases & 30 & & & .000 \\
\hline \multicolumn{2}{l}{ a. 2 cells $(50.0 \%)$ have expected count less than 5. The minimum expected count is 1.17.}
\end{tabular}

\section{BAHASAN}

Dalam penelitian ini, dievaluasi sebanyak 30 pasien multitrauma yang datang berobat di Instalasi Rawat Darurat Bedah BLU RSUP Prof. Dr. R. D. Kandou yang memenuhi kriteria inklusi. Berdasarkan data hasil penelitian, ditemukan penderita multitrauma lebih banyak pada jenis kelamin laki-laki (66,7\%) dibandingkan dengan perempuan $(33,3 \%)$.

Dalam penilaian cidera, pada penelitian ini menggunakan ISS untuk memudahkan pengelompokkan derajat trauma untuk pasien yang mengalami multiple trauma. Hasil penelitian memperlihatkan bahwa semakin tinggi nilai ISS, maka makin meningkat pula angka mortalitas suatu kasus multitrauma, dimana ada 26 pasien pada kelompok nilai ISS 1625 , yang mana 3 orang meninggal dan ada 4 pasien pada kelompok nilai 26-35 yang mana semuanya meninggal.

Pada penelitian ini juga mencoba untuk menghubungkan antara nilai ISS dan INR pada pasien-pasien multitrauma, dimana didapatkan hasil dari 30 pasien multi trauma kelompok pasien dengan nilai ISS $16-25$ yang nilai INR $\leq 1,5$ berjumlah 25 pasien dan dengan nilai INR $>1,5$ berjumlah 1 pasien, sedangkan pada kelompok pasien dengan nilai ISS 26-35 yang nilai INR $\leq 1,5$ tidak didapatkan, namun yang dengan nilai INR $>1,5$ didapatkan berjumlah 4 pasien sehingga dapat disimpulkan bahwa pada kasus multitrauma, dengan meningkatnya nilai ISS maka probabilitas meningkatnya nilai INR suatu kasus semakin besar juga.

Dari hasil penelitian juga didapatkan nilai INR dari semua pasien dengan kasus multi trauma, dimana dibagi kedalam dua kelompok nilai INR yaitu kelompok dengan nilai INR $\leq 1,5$ dan kelompok dengan nilai INR $>1,5$. Dari data ditemukan banyaknya pasien pada kelompok nilai INR $\leq 1,5$ berjumlah 25 pasien sedangkan pada kelompok nilai INR $>1,5$ berjumlah 5 pasien. Dari 25 pasien pada kelompok nilai INR $\leq 1,5$ didapatkan 2 kasus kematian sedangkan dari 5 pasien pada kelompok nilai INR $>1,5$ semuanya meninggal. Dari hasil penelitian ini dapat disimpulkan bahwa pada pasien multi trauma yang tidak memiliki risiko koagulopati yaitu dengan nilai INR $\leq 1,5$ mempunyai angka mortalitas yang rendah, sedangkan pada pasien multi trauma dengan risiko koagulopati dimana nilai INR $>1,5$ angka mortalitasnya jauh meningkat. 


\section{SIMPULAN}

Dari hasil penelitian dan bahasan dapat disimpulkan bahwa peningkatan ISS proporsional dengan peningkatan INR yang selanjutnya proporsional terhadap peningkatan angka kematian pasien multitrauma.

\section{SARAN}

Pemeriksaan INR pada pasien multi trauma di Instalasi Rawat Bedah dapat dilakukan untuk mengenali adanya risiko koagulopati pada pasien, sehingga bisa juga mengetahui mortalitas suatu kasus trauma.

\section{DAFTAR PUSTAKA}

1. D'Angelo MR, Dutton RP. Management of Trauma-Induced Coagulopathy: Trends and practices. AANA J. 2010;78(1):35-40.
2. Spahn D, Rossaint R. Coagulopathy and blood component transfusion in trauma. $\mathrm{Br} \mathrm{J}$ Anaesth. 2005;95(2):130-9.

3. Sixta SL, Hatch QM, Matijevic N, Wade CE, Holcomb JB, Cotton BA. Mechanistic determinates of the acute coagulopathy of trauma (ACoT) in patients requiring emergency surgery. Int J Burn Trauma. 2012;2(3):158166.

4. Frith D, Goslings JC, Gaarder C, Maegele M, Cohen MJ, Allard S, et al. Definition and drivers of acute traumatic coagulopathy: clinical and experimental investigations. $\mathrm{J}$ Thromb Haemost. 2010;8:1919-25.

5. White NJ. Trauma-Induced Coagulopathy: A clinical and scientific perspective. Washington: American Society of Hematology Division of Emergency Medicine, University of Washington, 2013; p. 660-3. 